\title{
Angus Maddison, Chinese Economic Performance in the Long Run; second edition revised and updated: 960-2030 AD \\ Paris, OECD, 2007, 213 pp.
}

Jean-Paul Maréchal

\section{OpenEdition}

Journals

Édition électronique

URL : http://journals.openedition.org/chinaperspectives/4956

DOI : 10.4000/chinaperspectives.4956

ISSN : 1996-4617

Éditeur

Centre d'étude français sur la Chine contemporaine

Édition imprimée

Date de publication : 31 décembre 2009

ISSN : 2070-3449

\section{Référence électronique}

Jean-Paul Maréchal, « Angus Maddison, Chinese Economic Performance in the Long Run; second edition revised and updated: 960-2030 AD », China Perspectives [En ligne], 2009/4 | 2009, mis en ligne le 13 janvier 2010, consulté le 21 septembre 2020. URL : http://journals.openedition.org/ chinaperspectives/4956; DOI : https://doi.org/10.4000/chinaperspectives.4956

Ce document a été généré automatiquement le 21 septembre 2020.

(c) All rights reserved 


\section{Angus Maddison, Chinese Economic Performance in the Long Run; second edition revised and updated: 960-2030 AD}

Paris, OECD, 2007, 213 pp.

Jean-Paul Maréchal

1 Angus Maddison is a specialist in questions of economic growth and development, and is best known for his overview published in 2001, The World Economy: A millennial perspective (OECD), in which he reconstitutes hundreds of statistical records to retrace the evolution of the global economy over more than ten centuries.

2 In Chinese Economic Performance in the Long Run (the first edition of which was published back in 1998) he gives us a mathematically documented history of the economic development of the Middle Kingdom from the late tenth century to the present, ending with a forecast for the next 25 years. The true interest of such a work, to which no summary overview can do justice, lies in the thousands of precise figures it contains, making it an inexhaustible mine of information for every researcher concerned with China. But this is where Angus Maddison shows his true talent: reading his books is never burdensome. His works provide a lively reflection on his topics, and while they are considerably enhanced and enriched by graphs and tables, these can be momentarily set aside by readers who wish to get straight to the point. This book follows a straightforward chronological line from imperial China (Chapter 1) to the author's forecast for the coming quarter century (Chapter 4), having passed through the vicissitudes that beset the Middle Kingdom between 1820 and 1949 (Chapter 3) and the developmental dynamics displayed by the country since 1949, especially after 1978 (Chapter 3).

3 The author shows how the centre of gravity of the Chinese economy shifted southwards between the eighth and thirteenth centuries. In the eighth century, three quarters of the population lived in the north, and their main crops were wheat and 
millet, whereas five centuries later three quarters lived south of the Yangtze and cultivated mainly rice. From the tenth to the early fifteenth century, per capita income in China was higher than levels attested for Europe. It was only between the fifteenth and eighteenth centuries that China yielded its economic lead to Europe, which was better suited for the birth of modern capitalism. There followed, from 1820 to 1949, a long period of "economic decline and humiliations from abroad" (p. 49). The establishment of the People's Republic of China reversed that trend. The author emphasises, for example, that despite the ravages caused by the Great Leap Forward (1958-1960), the Cultural Revolution (1966-1976), the country's isolation, the tense relationship with the Soviet Union and the United States, and the wars against Korea and India, China's GDP nonetheless tripled between 1952 and 1978. Meanwhile per capita income rose by 180 percent and labour productivity by 160 percent (p. 69), completely transforming the country's economic structure. The share of industry in its GDP rose from 8 percent to 52 percent, while the agricultural contribution fell from 60 percent to 16 percent (p. 80). This was followed by the turn towards market economy fomented by Deng Xiaoping in 1978. Between that date and 2003, GDP rose nearly sevenfold, real per capita income rose fivefold, and labour productivity quadrupled ( $\mathrm{p}$. 69). A single figure sums up the breadth of these transformations: per capita GDP underwent an annual growth rate of 6.6 percent. In 1990, China's GDP was less than half that of the Russian Federation, but by 2003 it was six times larger (p. 109).

4 By relying on calculations based on purchasing power parity (an approach which, unlike reliance on exchange rates, does not downplay the performance of China and other poor or developing countries in general ${ }^{1}$ ), Maddison shows that in 1978 China's share in global GDP was 5 percent, in 2003 it was 15 percent, and by 2030 it could reach 23 percent. Based on these calculations, China's GDP in 2003 stood at 78 percent of that of the USA, and more than double that of Japan (p. 117).

5 According to some scenarios, China should recover its former status as the leading global economic power by 2015. But of course, the economic crisis that broke out after the publication of this work has disrupted a number of assumptions and makes any forecast a risky undertaking. ${ }^{2}$

6 In addition to the trends mentioned above, Angus Maddison's work contains dozens of tables and graphs referring to various topics, such as population densities, GDP, agriculture, exports, etc., some of which are approached from a comparative international perspective. As a rich source of such data it is indispensable for anyone wishing to become fully acquainted with the economic history of one of the major players in the twenty-first century. ${ }^{3}$

7 Translated by Jonathan Hall 


\section{NOTES}

1. On this question and the consequent international reclassifications, see Norman Myers and Jennifer Kent, The New Consumers: The Influence of Affluence on the Environment, Washington, London, Covelo, Island Press, 2004.

2. See the excellent articles by Benoît Vermander, "La crise entre en Chine," Projet, no. 309, March 2009, pp. 45-50, and Valérie Niquet, "La Chine face à la crise," Perspectives chinoises, no. 3, 2009, pp. 86-93.

3. Interested readers may wish to follow the debate between Carsten Holz and Angus Maddison in the Review of Income and Wealth, 2006, following the Holz's criticisms of Maddison's book. Carsten Holz's latest response can be found online at: http:// ihone.ust.hk/ percent7Esocholtz/Maddison/?CH-response-to-Maddison-21March06.pdf (NDLR). 